\title{
Diasporic dialogues: The role of gender, language, and revision in the neo-slave narrative
}

\author{
Kalenda Eaton \\ eatonk@arcadia.edu \\ Arcadia University, USA
}

\begin{abstract}
In this article I examine the creation of neo-slave narratives, or fictional texts written in the $20^{\text {th }}$ and $21^{\text {st }}$ centuries, yet set during an imagined period of American slavery or indentured servitude. In these novels the authors, usually African-descended, depict slavery and/or plantation life, generally, to privilege the experiences of the slave. The process of actively writing against traditional plantation narratives of the $18^{\text {th }}$ and $19^{\text {th }}$ centuries can liberate slave histories and allows silenced actors to speak. However, in this paper, I argue that there is a danger of further marginalization when History is the platform for creative expression. I examine two novels whose authors employ the use of satire to discuss slave experience and by doing so, I explore how the images of Black slave and servant women can be either devalued or empowered depending on authorial representation and intent.
\end{abstract}

Keywords: slave narratives; women; African American; satire, historical fiction

\section{INTRODUCTION}

In the twentieth and twenty-first centuries, many authors have found their voices through the process of re-writing early African Diasporic experience. One product of this self-conscious act is the creation of the "neo-slave narrative"; a subgenre of historical fiction, which often address possibilities of slave experience, word play, and re-memory absent from many writings during the eighteenth and nineteenth centuries. Unlike fugitive authors, composers of recent narratives come from a position of relative privilege produced by a theoretical and chronological distance. These authors discuss slavery from the perspective of free citizens who have learned, but not lived, the history of societies in which their characters exist. In addition, the contemporary treatments are largely fictional accounts, whether they are historical narratives, "palimpsest narratives", "genealogical narratives", or a close imitation of the original slave narrative ${ }^{1}$. Freedoms with form and style, numerous literary movements, and Western

\footnotetext{
${ }^{1}$ For a detailed description of the Neo-Slave Narrative see Andrews et al. (1997).
} 
education have afforded writers the ability to re-create and re-historicize the text, thus liberating static representations of slave experience.

With creative freedom comes the opportunity to vindicate former fictional depictions of slaves and slave life, generally found in literature written by nineteenth and twentieth century white male and female authors. As early as the late nineteenth century, black authors began to question the literary standard for addressing slavery and swiftly provided alternatives to narratives that presented unsophisticated caricatures of plantation slaves that portrayed the "runaway" as treacherous and the unloyal slave as “vile”. Examples of these rewritings include works by Pauline Hopkins, Charles Chesnutt, William Wells Brown, Victor Séjour, and others who used their literacy to reinscribe history. Throughout the twentieth century, the relative distance from a slave past coupled with increased educational access and freedom of expression created a literary environment ripe for intellectual query and liberty with form, style, and subject matter.

Though most writers create full characters seriously wrestling with the hardships of their slave (or neo-slave) experience, others reproduce important parts of this re-reading in a satirical or parodic form. Contemporary writers concerned with slavery see themselves disrupting the typically sensitive nature of the subject by actively confronting accepted realities of the capitalist enterprise. Interestingly, the choice to use satire to convey early black American experience is more than experimentation with craft. Several authors are paying homage to the persistent satirical tradition that exists within African Diasporic oral culture which was later transferred to the black written text. For example, in an essay on “Third World Aesthetics”, novelist and literary critic Gayl Jones proclaims:

I am a novel of the Third World, and so you would expect me to be different from those other novels, to have a different aesthetic, to revise (or rewrite) genre, characterization, style, theme, structure, viewpoint, values, and so I do. Paradox and ambivalence may be seen in the margins of this marginal text; and may be read in and between then lines. Satire and irony is plentiful here, for it's part of my tradition. (Jones 1994: 508, emphasis added)

Likewise, in a separate essay Harry L. Jones argues, "For three hundred and fifty years, black humor has been a survival technique and a weapon of the weak against the strong” (Jones 1969: 3). Both scholars speak to the ways "black" or "Third World" people use satire and humor to react to their environments, a skill that is consequently 
reproduced in black literature.

When considering the empowering use of humor or satire in the neo-slave narrative one must also be aware of ways "new" narratives can reinforce the same gender and racial stereotypes writers are attempting to subvert. For example, in the novels Flight to Canada and I, Tituba, Black Witch of Salem Ishmael Reed and Maryse Condé (respectively) complicate the relationships between oppressors and oppressed in deliberate ways. The authors skillfully bend bondage narratives to address intricacies of black slave experience, Africans in the Diaspora, capitalism, free choice, and the master-slave dynamic ${ }^{2}$. However, the novels produce challenging depictions of black male/female relationships which seem to argue against attempts at collective rebuilding and inclusion. Conversely, one can also argue that any interpretation by black writers of a "system" as deleterious and demented as slavery can be read as a revolutionary act, regardless of the content or the satirical style.

\section{FLIGHT TO CANADA}

Written in response to the lack of black male protagonists in $19^{\text {th }}$ century slave narratives; Flight to Canada, Reed's early novel about the economics of slavery, the power of literacy, and impossibility of escape, curiously employs black female characters as comic relief in an attempt to vindicate the fully developed male characters. This move assumes black women have the power of collective agency, absent in communities of black men, which allows them to withstand unfavorable images. Therefore, the use of parody and satire becomes intricately tied to a (mis)read of gender dynamics within the black slave community in the authors' attempts to rescue the male figure from the annals of history. In Warriors, Conjurers, and Priests, Joyce Ann Joyce notes, "Not surprisingly, one of the most important problems in scholarship on [Ishmael] Reed involves his negative characterizations of Black women” (Joyce 1994: 244). She then continues to argue in Reed's favor and states, “Though he challenges

\footnotetext{
${ }^{2}$ This is not to say that these authors are the only using satire to comment on social relationships and/or racial injustices. I am aware of the long-standing tradition of satirical writing within the African American literary tradition. For example, Langston Hughes, Wallace Thurman, Gloria Naylor, Ralph Ellison, Mel Watkins, Charles Chesnutt, and Toni Morrison, are just a few that are noted for their satirical works.
} 
societal evils, he is not didactic, and no one, neither man nor woman, escapes from his novels unscathed” (Joyce 1994: 269).

In the introduction to the Ishmael Reed Reader Reed acknowledges that in Flight to Canada he "refers to four slaves who represent the different approaches used by Africans to deal with the situation in which they found themselves” (Reed 1976: xxi). In the narrative, it appears that Reed rewrites their experiences in satirical form to give the characters agency to decide their fate. When examined more closely there is a definite distinction between the agency given to the male characters and the agency taken by the female characters. Therefore, the question regarding the depictions of the black female characters is: what exactly is Reed rewriting?

Reed's novel follows Raven Quickskill's escape from a southern plantation and the effect his flight has on the remaining inhabitants. He is able to write himself into being with crafty poetry and frequent letters detailing his exploits in the northern United States. Through his satirical representation of $19^{\text {th }}$ century America, Reed challenges Abraham Lincoln's rhetoric, white gentility, and the "cult of true womanhood", while also exposing the exploitation of the fugitive slave on the lecture circuit and Harriet Beecher Stowe’s “theft” of Josiah Henson's life story among other tantalizing historical truths. Reed uses the space of the novel to tackle the weighty issue of black complicity in the slave system as well as cross-racial intimacy (cordial, not romantic) fostered by the isolation of plantation.

At first glance, Reed's unbalanced depiction of black female and male characters in the novel supports Hazel Carby's statement that, “The institution of slavery is now widely regarded as the source of stereotypes about the black woman” (Carby 1987: 20). For example, throughout the text Reed positions the mammy figure ("Mammy Barracuda”) in direct contrast to the vilified Uncle Tom (“Uncle Robin”) character. She accurately embodies her namesake (Barracuda), with her vicious attacks on every slave in the narrative and the unrelenting torture of her white mistress. In Reconstructing Womanhood, Carby continues to argue that stereotypes of the black slave woman adversely affect contemporary perceptions of black women. Given this knowledge, it is possible to understand Reed's conscious decision not to depict the humble, docile, selfless "mammy" that appears in antebellum (and Reconstruction era) literature written 
by white American authors. That idealized mammy was a construct of white sentimentalism and ignored the real properties of her womanhood and family life.

Where the traditionally popular mammy figure was maternal, asexual, selfless, caring, plump, and jolly, Flight to Canada's Mammy Barracuda parodies these characteristics. She retains the maternal qualities in the sense that her white charges can "curl up fetus like in [her] lap" and be "rock[ed] in the rocking chair" (Reed 1976: 20-21). She also provides the Swille's with opium-induced comfort by calming them with an injection when they are unable to handle the pressures of plantation life (Reed 1976: 108-9). While Ishmael Reed reconstructs the asexual, effeminate characterizations of the historical "Uncle Tom" by including the fact that Uncle Robin is married and very sexually active; conversely, the asexual Mammy experiences very little change in the perceptions of her sexuality. The major deviation in her behavior remains her excitement by the possibility of tormenting other slaves with "whips and chains". Accordingly, in the novel she uses these tools to inflict pain in a disturbing sadistic fashion.

Though it is obvious Reed uses these and other deliberately ludicrous scenes to comment on problematic notions of gender in the antebellum South, the Mammy becomes a female version of a cad. Earlier in the novel, she is described as wearing a "silk scarf" that replaces the traditional worn, tattered "head rag". The presence of silk attests to her prominent position in the Swille household and assumes much more. As the text infers, Mammy receives her jewels and riches from "Arthur" (whom the other slaves know only as "Massa Swille") in exchange for her numerous services including prior sexual encounters. Her hinted at, but unstated relationship with the master boldly addresses the complicated narratives surrounding sexual activity and subservience on the plantation. In an infamous book review of Flight to Canada, Sondra O’Neale argues, “...for the black woman Reed intends no sympathy; as represented by Swille's human cudgel, Mammy Barracuda, whose whore-begotten wealth is so heavy that it bends her back and [is used] to 'blind' her master's slaves (O’Neale 1978: 174177).

Within Reed's description of Mammy's possessions is a parody of the perceptions surrounding the religious and self-righteous slave woman. The 'blinding' element to 
which O’Neale refers is a diamond crucifix on Mammy Barracuda's bosom, which is "so heavy she walks with a stoop". Later in a conversation between Uncle Robin and his wife, the reader learns that Mammy formed a "Jesus-cult” that was put in place to stamp out the heathenism - of African slaves. The pointed critique of imbued Christianity as opposed to an embrace of polytheism or a form of "African spirituality" places her at the forefront of the debate over the acceptance of the "white-man's religion” and the appropriation of European culture. Also in the text, Barracuda proudly "waltzes" out of the room with Abraham Lincoln and she proudly sings at the "last reunion of Confederate soldiers” as a testament to where her true loyalty lies (Reed 1976: 39, 14).

Again, one can argue that all of the aforementioned acts add to and support Reed's critique of the stereotype of the plantation mammy's undying love for white Southern livelihood. However, a more critical look questions if Mammy Barracuda’s actions do anything to relieve the black woman who has often been accused by those in her own ethnic community of being a servant, lover, and supporter of white patriarchy from time immemorial. No matter how ridiculous the package, in this novel, Mammy Barracuda appears to fulfill her culturally supported role and for the unskilled reader may not be a deviation from the plantation tradition that Reed mocks.

For example, in one poignant exchange between Mammy and Mrs. Swille, Reed uses mammy’s power to “attack” (literally) nineteenth century demands for women's suffrage that ultimately eschewed the positionality of black women. Throughout the novel Mrs. Swille stages a one-woman protest against her husband. She attempts to align herself with the injustices on the plantation when she accuses her husband of treating her as a slave in her own home. She stages a dramatic protest scene in her room and claims that all disadvantaged people (primarily women) regardless of color are fighting the same struggle against white patriarchy. Subsequently, Master Swille grants a terribly annoyed Mammy Barracuda permission to make Mrs. Swille “act right” by any means necessary — once again suggesting collusion between the master and black former mistress who now runs his home. Barracuda uses this opportunity to beat Mrs. Swille, "grab her hair and throw her to the floor", and "give her a football-punt kick to her naked hip, causing and immediate red welt” (Reed 1976: 112). The abuse continues until Mrs. Swille is finally “cleaned up” and given an injection of barbiturates to help 
her sleep. Soon after, Mammy Barracuda assures Mrs. Swille that she was doing this for her own good and that she "hates to do what she had to do with her darlin" (Reed 1976: 114).

Through parody, Reed appears to vindicate the "traditional” mammy by demonstrating her actual power, supplying a voice, and making her the epitome of the "strong black woman”. Unfortunately, she remains stereotypical in other, more complex ways as she is transformed from one image of black womanhood into another. Interestingly, with the flick of a pen the traditionally accommodating "mammy" becomes the vile "Sapphire". In an excerpt from Ain't I a Woman, bell hooks asserts,

As Sapphires, black women were depicted as evil treacherous, bitchy, stubborn, and hateful, in short all that the mammy figure was not...White men could justify their dehumanization and sexual exploitation of black women by arguing that they possessed inherent demonic qualities...And white women could use the image of the evil sinful black woman to emphasize their own innocence and purity (Hooks 1999: 85).

Though comedic in nature and possibly political in intent, Mrs. Swille's violent encounter with Mammy Barracuda places her on the receiving end of the mammy’s rage preserving her womanhood and demonizing Barracuda. Mrs. Swille is depicted as a helpless victim of Mammy's oppressive aggression. One can argue that the above scene confronts the fallacy that "sisterhood is global” and reproduces Black women's feelings of betrayal during the height of exclusivity in the second wave of the feminist movement. Or, on the other hand that the satirical framework created for the text blurs the real meaning behind the action. The question then becomes, why is it when confronted with white womanhood the Black woman's (alleged) internalized violent and destructive feelings can only manifest in the pages of a text written by a male author?

Mammy Barracuda remains a troubled character throughout the narrative. The fact that she is only one of three African American females used in the novel to depict a portion of slave life is additionally problematic. Uncle Robin's wife, “Aunt Judy”, exists in the novel as a "bedmate" and rarely, if ever, leaves the confines of their home. Mammy Barracuda's sidekick, "Bangalang”, is an incomplete representation of anything substantive as she is depicted as a floundering, senseless woman. For example, in one scene she leaves the water running because Mammy did not tell her to turn it off. Later, when Uncle Robin reluctantly attempts to extinguish Master Swille (who is ironically 
set aflame by his own Poe-esque gothic incestuous desires), she impedes his progress by stopping the water - because after the previous incident, Mammy told her "when you turn the faucet on, you're not suppose to forget to turn it off” (Reed 1976: 136-7) 3 $^{3}$ In sum, many representations of black women in the novel appear as "comic capital"4, at more intelligent points in the novel.

It is obvious to the reader that the "Mammy" character in Flight to Canada is not supposed to be fully redeemed. She is overbearing, emasculating, and a close second to the myth of the black matriarch detailed in documents like "The Moynihan Report" released a decade prior to the publication of Reed's text ${ }^{5}$. In defense of Reed, Linda Hutcheon argues:

Reed is always serious, beneath his parodic play. It is this basic seriousness that critics have frequently been blind to when they accuse postmodernism of being ironic-and therefore trivial. The assumption seems to be that authenticity of experience and expression are somehow incompatible with double-voicing and/or humor. This view seems to be shared not only by Marxist critics, but also by some feminist critics. And yet it is feminist writers, along with blacks, who have used such ironic intertextuality to such powerful ends-both ideologically and aesthetically (if the two could, in fact, be so easily separated) (Hutcheon 1988:134).

In slight opposition, Sondra O’Neale argues, “The moral [regarding Flight to Canada] is not an aesthetic one-but then a stance of the black Aesthetic is that political and humanistic statement is an undeniable force in art. If Reed purposes to free the black man with his writing, let us hope that he will magnanimously enlarge his vision to free all the race...” (O’Neale 1978: 177). While championing the power in narrative, O’Neale calls for a realistic view of the "political”.

Can one fault Reed when he purports, "My writing is real cutup, it’s provocative, and I make no apologies about that" (Carroll 1995: 193)? Or is it true that "there is generally never a one-to-one correspondence between what a novel is and who/what a novelist is" as Gayl Jones argues? Even if the "blame” is not on the author, per se, and/or rests in the representation of the female characters by other male characters, (e.g. Charles

\footnotetext{
${ }^{3}$ Her character is reminiscent of minstrel characters, like Stepin Fetchit, and other daft characterizations of African Americans in early American cinema. Generally men, these accomplished actors perpetuated the stereotype of the "foolish Negro" in order to retain employment. An allusion is also made to Prissy, Butterfly McQueen's flighty character in the cinematic version of "Gone with the Wind" who famously confesses, “I don't know nothing 'bout birthing no babies”.

${ }^{4}$ Term used in Elizabeth Muher's essay, "Isadora at sea: Misogyny as comic capital in Charles Johnson's Middle Passage”. African American Review: Winter 1996.

${ }^{5}$ For further analysis of the black family as perceived by Moynihan, see Rainwater and Yancey (1967).
} 
Johnson's Middle Passage), does understanding that satire is a playful form or style sufficiently address the larger issue of re-presentation?

As O’Neale articulates in her argument, there is a definite connection between stories and experiences of all African American people, specifically during slavery. The opportunity to rewrite the narratives of experience and reread "unsaid truths" should not have to privilege one story over another. In Flight to Canada, Mammy Barracuda misses the opportunity to salvage her 'mammyhood' and escape a prescribed lifestyle. At the novel's end, Master Swille’s "last will and testament" relocates her to a "school for Negroes” where it states, she can continue her sadism as headmistress.

In an attempt to fully explain Reed's project, Ashraf Rushdy contemplates the many positive elements of Reed's work. He writes,

[Reed] offers a parody of slave narratives as they were read as a way of reconstructing potential readings of slave narratives as they can be read...a parody that renders Uncle Tom's Cabin obsolete simultaneously opens up the possibility for fresh readings of those co-opted slave narratives (Rushdy 1999:125).

He later argues, “according to Reed, 'HooDoo writing' is essential to the act of collective healing necessary for slavery to end its influence on the behavior of its survivors" (Rushdy 1999: 130). It is important to reiterate that the primary agenda of these novels is the reclamation of a black manhood that is lost and/or absent in the literature of white American authors. For Reed, the goal may be to vindicate Harriet Beecher Stowe's "Uncle Tom” (and Josiah Henson) through his Uncle Robin and Raven characters. In the now classic critical text, The Signifying, Monkey: A Theory of Afro-American Literary Criticism, Henry Louis Gates, Jr. discusses the reproduction of canonical literary conventions through the language of the black vernacular. He writes,

\footnotetext{
Black literature shares much with, far more than it differs from, the Western textual tradition, primarily as registered in English, Spanish, Portuguese, and French. But black formal repetition always repeats with a difference, a black difference that manifests itself in specific language use. And the repository that contains the language that is the source-and the reflection-of black difference is the Black English vernacular tradition. (Gates 2000 342-343)
}

The location of the "difference" is at the heart of the matter for scholars reading the male and female characters in the neo-slave narrative. Reed dispels myths about black male experience during slavery when the text provides clear opportunities for the male slaves to redeem their former selves by giving voice to their histories. Conversely, through this model and use of satire as a weapon, black female characters remain 
caricatures placed in the margins of history, as she is denied equal space with her male counterparts, or a voice of her own.

\section{I, TITUBA, BLACK WITCH OF SALEM}

Therefore, if satire and gendered re-presentations of slave life work in tandem how does one reconcile a novel written by a woman of the Diaspora that recalls the life of a forgotten black woman whose very presence in the New World was considered the cause of legendary witchcraft hysteria in the $17^{\text {th }}$ century? More importantly, how do we read this novel when, in reference to the protagonist, the author warns us afterward: "Do not take Tituba too seriously, please” (Scarboro 1992: 212). In I, Tituba Black Witch of Salem Maryse Condé does not shy away from parody in her refashioning of servitude in New England. Although she decides to privilege orality, recovery, and feminine control she openly admits to infusing I, Tituba with comic irony and satire, possibly taking a cue from other early regional black texts ${ }^{6}$. What is interesting about her account is the equal space given to multiple voices alongside clever uses of parody and satire.

Condé retells the story of Tituba Indian; a historical figure denied a voice before and after she becomes a footnote to the controversial Salem Witch Trials of $17^{\text {th }}$ century colonial Massachusetts. She is the sole blame for the debauchery among the accused women as her "black magic" is believed to be the source of witchcraft in the village. As a result of her silencing, Condé's fictional Tituba modifies Western concepts of language in an effort to preserve her life. The author conjures an intricate tale that enables Tituba to project her voice through alternate means of communication; not only freeing the subject, but also allowing her the freedom to parody various episodes of historical memory.

Throughout the text it is proven that speechlessness operates as a force that signifies more than mere silencing. Because the events take place in a colonial space prior to fullscale geographic expansion and trans-Atlantic slavery, suppression took many forms. For example, denying and/or inhibiting speech by enforcing a foreign tongue on the oppressed extends the realm of power and remains a destructive by-product of

\footnotetext{
${ }^{6}$ See Elizabeth Breau's (1993) discussion of the uses of satire in the New England slave narrative Our Nig.
} 
colonization. A prime example of the colonized tongue rests with the Trans-Atlantic or African slave trade, where research suggests slaves from corresponding African nations and linguistic backgrounds were separated as a means of deterring possible uprisings on the plantations of the West Indies and the American South. In exchange for the African slave's physical and psychological subjugation, the dominant (i.e. European) discourse was mandated as the only system of effective communication with the colonizer and slave master.

In the historic essay, "On National Culture”, Frantz Fanon posits, “The effect consciously sought by colonialism was to drive into the natives' heads the idea that if the settlers were to leave, they would at once fall back into barbarism, degradation and bestiality” (Fanon 1999: 37). The threat of abandonment speaks to an almost infantile dependence on the colonizer and a rejection of native customs and folkways. What Condé and other post-colonial authors attempt is the "further creation" of the colonized language in a "new context, under new conditions” (Bakhtin 1998: 535). Through the use of satire, I, Tituba, directly acknowledges the issue of an authoritative presence that attempts to cancel out the voice of the subject.

In “Tituba's Story”, Bernard Rosenthal gives an account of the facts known about the historical Tituba's existence. He notes, "the facts are few" and examines how over the years a majority of the knowledge about Tituba can be traced back to fictional constructions by either authors such as Condé or "historical speculation”. He notes that:

\begin{abstract}
She lived in the household of the Reverend Samuel Parris. Her prior whereabouts are not known. Her culture defined her as an Indian. Her contemporaries offered no verifiable clues about her age. She was accused of witchcraft and confessed. She claimed to have been beaten and to have been herself afflicted by witches. From the beginning of March 1692 until she was brought to a court of General jail. Delivery on 9 May 1693, she presumably languished in prison. Exactly when she was released and whether she was ever reunited with John Indian-or whether she had reason to be-is also not known (Rosenthal 1998: 200).
\end{abstract}

This account of Tituba's life exhibits the same stolid reportage as her actual court deposition. Tituba exists as an intangible being attached to a name but detached from society. Aime Cesaire calls this the "thingification" of the colonized person. She has no active participation within the environment in which she is placed and is virtually ignored by all who surround her. In Postcolonial Theory, Leela Gandhi notes, "the 'third world woman' can thus be seen as yet another object of Western knowledge, simultaneously knowable and unknowing” (Gandhi 1998: 86). 
However, it is in the novel that we see Condé's Tituba differ from the silenced historical subject. Tituba, the fictional character, lives a vibrant, subversive life. A revision of this kind is possible because Condé refuses to claim the historical Tituba. The author adamantly denies that the novel is a work of historical fiction, and chooses to create a character from her own imagining. Through this process, Condé has the freedom to play with convention (as does Reed), but notably steers clear of the caricatures discussed above. She identifies her text as the "opposite of a historical novel” noting that she "was not interested at all in what her real life could have been” (Scarboro 1992: 201). The lack of a model gives Condé nothing to reinforce, react to, or push against, again, making it possible for a more balanced rendering of the figure.

Condé's Tituba is first introduced as the product of rape, conceived on the slave ship Christ the King, en route to Barbados. These first lines of the text hint at Condé's hidden mission to disrupt serious imaginings of the character. While there is the obvious juxtaposition of domination and forced enslavement with the image of the religious savior (Christ), Tituba's conception and nativity tale does much more. In her discussion of subversion in the novel, Paula C. Barnes notes, “Condé's adoption of the structure of the nineteenth-century slave narrative is completed in the narrative itself... [but] as seen with the pre-and post-narrative conventions, Condé consciously imitates, manipulates, and revises these tropes (Barnes 1999: 196). Barnes goes on to discuss the description of Tituba's conception as an attack on the trope of the slave narrative which includes 'a first sentence beginning 'I was born...,' in other words, the tracing of Tituba's conception back to the act of rape on a vessel moving across the Atlantic situates her as the quintessential Diasporic subject, whose "circumstances surrounding [her] birth become more prominent than the birth itself” (Barnes 1999: 196).

Later in the text after Tituba is accused of witchcraft and jailed, Condé allows Hester Prynne, the victimized figure of Nathaniel Hawthorne's The Scarlet Letter, to enter into the novel. Hester and Tituba share a cell, providing commentary on the effects Puritanical values have on free-thinking women. In Conde's version of Hester's life she commits suicide after Tituba's testimony but remains a significant force in her life through the foresight of Mama Yaya or Yao, her spiritual protectors throughout the novel. While the act of placing a figure like Prynne in the novel can be read as a testament to shared experiences among women or an affront to colonial patriarchy, 
according to Condé, Hester's appearance in the novel is a reaction to the contemporary moment. In response to an interview question about Prynne's presence she states: "Writing Tituba was an opportunity to express my feelings about present-day America. I wanted to imply that in terms of narrow-mindedness, hypocrisy, and racism, little has changes since the days of the Puritans" (Scarboro 1992: 203). This revelation moves the reader away from the symbolism existing within the text (racial and gendered unity), instead using women's lives to emphasize the progressive failures of the country. Also, there are several layers of pastiche present in this scene. For example, the black author (Condé) lends her voice to Prynne, an ostracized white woman, unwed and a mother, originally created by a white male author. Prynne's capture and bondage in the prison cell of her novel (I, Tituba) ultimately gives Condé, not Hawthorne, control over who holds the key.

In similar moments, Hester Prynne appears long enough to teach Tituba how to tell a true story that will allow her to survive and to introduce her to the future teachings of feminism. She also becomes a major part of Tituba's "text of silenced history” when she structures Tituba's testimony (Dukats 1995: 54) and instructs Tituba to "make them scared” and "give them their money’s worth!”, suggesting that her words and actions become the spectacle (Condé 1992: 99). After Hester’s advice, Condé inserts the official deposition, giving validity to the scene, but also questioning the "truth" the world has accepted about Tituba. Including Hester's advice in the novel can also be read as an attempt to answer why, outside of the fiction that structures the novel, the factual deposition reads as if Tituba is actually coerced into saying what her accusers wanted to hear.

In Black Skin, White Masks (1967) Fanon asserts, “to speak is to exist absolutely for the other". Following this sentiment in relation to the historical Tituba's court deposition, the act of speaking and the words she mimics create for the court a level of truth to the accusations of witchery, whether they are her truth or not. Her accusers pay close attention to her phrasing and extract meaning in order to build their case, but ironically, the testimony Tituba gives is puzzling as it is extremely contradictory and illogical. Likewise, the line of questioning is confusing and indirect. For example, the beginning of the original deposition reads as follows (note: the original spelling, punctuation, and terminology have not been altered): 
(H) Titibe what evil spirit have you familiarity with

(T) none

(H) why do you hurt these children

(T) I do not hurt them

(H) who is it then

(T) the devil for ought I know

(H) did you never see the devil.

(T) the devil came to me and bid me serve him

(H) who have you seen

(T) 4 women sometimes hurt the children

(H) who were they?

(T) goode Osburn and Sarah good and I doe not know who the other were Sarah

good and Osburne would have me hurt the children but I would not shee furder saith there

was a tale man of Boston that shee did see

(H) when did you see them

(T) Last night at Boston

(H) what did they say to you they said hurt the children

(H) and did you hurt them

(T) no there is 4 women and one man they hurt the children and then lay all upon me

and they tell me if I will not hurt the children they will hurt me

(H) but did you not hurt them

(T) yes, but I will hurt them no more... (Games 2010: 176-77)

In the larger document, Tituba vacillates between knowing and not knowing an "evil spirit”, being told by humans and then animals to "hurt the children”, and later hurting the children, not ever hurting the children, and/or refusing to hurt them again. Condé recognizes how the multiple circumstances surrounding the deposition, including the atmosphere outside the courtroom leaves the interpretation of Tituba's inconsistencies wide open. In response, she depicts Tituba as a cunning individual who spins the testimony in several directions for dramatic effect, thus doing as Hester suggests and "giving them what they want". Toward the end of the deposition the fictional Tituba adds, “I confess I wasn't a good actress”, revealing a “truth” about her role in the alleged incidents that caused the hysteria (Condé 1992: 106). By including the term 'actress' which suggests an invented persona, Condé consciously calls into question the innocence of the most sympathetic characters in the novel and humorously responds to the awkward nature of the testimony and her own use of satirical forms.

In other ironic moments, the fictional Tituba is depicted as an herbalist who uses her mystical power and knowledge of garden herbs to heal. The irony exists in the fact that her ability to use this natural craft is the premise behind the Salem hysteria. Tituba is first introduced to what the Puritans call "witchcraft" and what she deems education about herbs, by Mama Yaya, her surrogate mother. Though this is her first experience,

\footnotetext{
${ }^{7}$ Condé's text preserves much of the original with only a slight deviation in her creative choice to modernize the language and provide excerpts rather than the full draft of the deposition.
} 
her mother has the ability to "conjure up all the forces of nature" when she is pregnant with Tituba (Condé 1992: 4). Mama Yaya teaches Tituba the art of conjure in order to ensure Tituba's survival and to pass on a legacy that will be lost when she dies. Because of her knowledge, Tituba is revered by the slaves on the plantation in Barbados and news of her powers spreads across the island. Condé admits that this rendering of Mama Yaya is a part of Tituba's existence as a "mock-epic" novel. In the aforementioned interview, Condé is nonchalant in her response to the spiritual and empowering read of the novel. With regard to the omniscience of Mama Yaya, Tituba's spiritual guide, Condé states:

\footnotetext{
The question of grandmothers telling stories and thus teaching their granddaughters how to become writers is one of the biggest clichés of black female writing. I repeat that the element of parody is very important if you wish to fully comprehend Tituba...If one misses the parody in Tituba, one will not understand, for example, why she meets Hester Prynne in jail and why they discuss feminism in modern terms. Similarly, the presence of the invisible (the conversations with the mother and with Mama Yaya) is deliberately overdrawn (Scarboro 1992: 212).
}

In addition to spiritual power, Condé gives space and command to Tituba's burgeoning sexuality. She uses this power to resist the domination associated with slavery and combats her subjugation by loving freely in an environment where sexual satisfaction is condemned. Her subsequent relationship with John Indian highlights her inability to "do without men". In order to satisfy her "uncontrollable desire" she does the unthinkable and willingly subjects herself to a life of slavery (Condé 1992: 19). Condé’s portrayal of Tituba as a candidly sexual being writes Tituba into a femininity that transcends the boundaries created by her European female counterparts. For it is during her jailhouse conversation with Hester Prynne that she is told she cannot be regarded as a Feminist because of her overtly sexual image; a statement that recalls racist claims of licentiousness and bestiality among African women beginning in the sixteenth and seventeenth centuries (Condé 1992: 101). Additionally, the link Prynne makes between Tituba's sexual desire and resulting inability to be a true feminist cleverly addressed the stereotype of an asexual or lesbian feminist whose love of herself or other women restricts her ability to love men (because, as it is thought, heterosexual love is counterrevolutionary).

After her infamous testimony, Tituba remains in jail until she is "rescued” by the Jewish merchant Benjamin Cohen d'Azevedo. Her release into his custody was a release not only from the walls of the jail cell but also from the walls of institutional racism in 
which she resided for many years. In her relationship with Benjamin, Tituba allows her sexual desire to transcend race and transforms a typical master-slave act of physical domination into one in which she is reborn and in full control of her body. Instead of being “another master, another bondage” (Condé 1992: 120), Benjamin allows Tituba into his family and treats her as a person rather than a slave. It is important to note that Tituba is his property and unable to "walk away" from any sexual advances that he makes towards her, but she makes no attempt to end the relationship and looks forward to their nights together. Tituba reclaims the body that is so easily sold into bondage by enjoying the sexual relationship she has with Benjamin. Tituba's text signifies on that of slave women who when faced with the demand to render their bodies chose to take any possible control over the situation.

In Reconstructing Womanhood, Hazel V. Carby examines the reconstruction of "traditional" roles and identity as they relate to the slave narrative of Harriet Jacobs. In her autobiography, Incidents in the Life of a Slave Girl (1861), Jacobs uses her body in order to save the lives of her future children. She becomes a willing participant in a sexual relationship with a white man she does not love so that she may arrange for their continued safety. In a plea to the reader, she expresses the sentiment that "a slave girl ought not to be judged by the same standard as others” (Jacobs 1987: 386). Though Tituba's act is not a desperate plea for a child born "free” in an environment of slavery, she embodies the desperation set forth by Jacobs.

As Tituba matures and is released from Benjamin, she returns to Barbados and finds herself in a situation where Christopher, the leader of a maroon camp, attempts to strip her of self-esteem. It is significant that Condé chooses a Jewish merchant as the person able to free Tituba mentally as well as physically and then return her to her native land-while a Caribbean man subjugates her upon her return. Condé adeptly demonstrates the universality of patriarchal oppression. With Christopher, Tituba is demoralized when he calls her "a common negress" and professes that there is "no song for her". He refuses to divulge a plan of escape among the maroon's on the island and instructs that her only duty is to "make love". Tituba counters this sentiment by leaving Christopher and 
joining with another (Iphingene ${ }^{8}$ ) as leader of a slave rebellion, for which she ultimately gives her life. She knows the revolt will not be successful and repeatedly refers to it as the "final act/attack". Tituba's involvement and willingness to die for the revolution purposefully positions her as the antithesis of the marginalized woman who is voiceless and denied access to the native struggle.

The question of primary loyalty to race or gender that activist women of color encounter surfaces in Tituba's relationships with Christopher and Iphingene. Tituba answers this question in her earlier decision to follow John Indian into servitude and continues the pattern until she joins the preparation for the revolt towards the end of the novel. In Salem, when she speaks back to liberal Anglo-American feminism and redefines the premise of the sexual master-slave relationship she presents other complicated responses to the place of black womanhood in the New World as well.

Again, it is only when she thinks of Hester's feminist standpoint and the restrictions it places on highly expressive acts of passion that Tituba wonders if something is wrong with her sentiments. She remembers Hester's proclamation telling her that she is "too fond of love” and temporarily questions her feelings (Condé 1992: 170). In The Tongue Snatchers, Claudine Hermann also examines love and the feminist agenda. In terms of the historical silencing of women and their propensity to question the attributes that Hester repeatedly associates with feminist discourse, Hermann states that "Love... can not defend itself. Love's business isn't to prove. It has no use for being right" (Herrmann 1989: 56). Tituba seems to realize the triviality of using the dominant discourse to examine her actions. Returning to the interview, Condé admits she "wanted to turn Tituba into a sort of female hero, an epic heroine, like the legendary 'Nanny of the maroons (Scarboro 1992: 201)"” Therefore, it is important to question whether Condé is successful in providing Tituba true agency as an author of her own destiny as opposed to an illusory invention of the writer's consciousness.

Leela Gandhi notes “liberal academic feminism is said to silence the 'native woman' in its pious attempts to represent or speak for her” (Gandhi 1998: 89). Is this silencing present in Condé's attempt to give Tituba a voice or is she successful in eliminating her

\footnotetext{
${ }^{8}$ Iphingene's name is likely an invented masculine version of "Iphigenia" the ancient Greek figure designed to be a sacrifice that would aid her father's (Agamemnon) defeat of Troy. This read would be appropriate given Iphingene's sacrificial act on behalf of the island slaves.
} 
own presence and allowing Tituba to speak? Mudimbé-Boyi argues that Condé removes herself from the position of narrator and fully allows the spirit of Tituba to take control. Though Condé physically constructs the novel, Mudimbé-Boyi makes the distinction between Condé’s voice and Tituba’s voice. By giving Tituba a voice, Condé allows a voice to "emerge from elsewhere than from an 'authority' or from the social location of the writer” (Mudimbé-Boyi 1993: 753). The importance is that Condé has "created a territory for her in history and literature, allowing her to survive as a black female literary character, if not a historical figure” (Mudimbé-Boyi 1993: 755).

Despite the serious subject matter, Condé admits to hesitating "between irony and a desire to be serious" instead reaching a middle-ground that is the novel's current form (Scarboro 1992: 201). Her references to contemporary novels, gender theory, and popular culture remind the reader of her satirical hand. She introduces the term "feminist" in the late seventeenth century as opposed to having it reside in its actual birthplace of the nineteenth century. The same is also true with references to "strange fruit” the poem and later song made famous by Billie Holiday that laments bodies of lynched African Americans hanging from southern oak trees. These insertions prove that Condé chooses not to surrender all of her creative agency in telling Tituba's story and decides to incorporate satire as an act of rebellion.

Since the publication of the novel, scholars have gone back and questioned the true import of pivotal scenes like the one where Yao names Tituba (thought to be a scene gleaned from Alex Haley's Roots) or the reoccurring themes of feminism, racial identity, literacy, and sexuality (Scarboro 1992: 222, Barnes 1999: 197-201). Several have heeded Condé's words and not taken Tituba or the novel 'too seriously,' instead choosing to focus on the reasons the author subverts convention and/or parodies traditional forms. Likewise, the question of whether Tituba or Condé has the authority of speech should be considered in the continued analysis of Tituba's character along with the question of whether Condé is an appropriate spokesperson for the bondswoman. 


\section{CONCLUSION}

For writers like Condé the act of giving a voice is similar to that of giving life. She is able to fill "the silence and voids with voice and presence” (I, Tituba xii) and occupy a space that has been closed off in the pages of history. Though many work to fill in the gap, there remains a deafening silence in relation to the representation and agency that is "allowed" the formerly colonized individual. This silence is the result of a continued dominance in the public sector, including institutions of higher education and the media. The privilege of re-creation afforded Reed and Condé supposes a nuanced revision history. For the Diasporic author who takes it upon herself to retell the "truth" one of the main purposes of rewriting history is to heal stories and souls damaged by marginalization and suppression.

However, I note that when satire is used in the text a clever "messiness" is created that often places artistic license at odds with national and/or cultural memory. Likewise, the authors' writing style and language use can create wholly unsympathetic characters whose presence causes the reader to question the role of the historical narrative. The examples of "fresh readings" and "acts of collective healing" allows for reconsiderations of history, memory, and truth. Therefore, it is imperative that one reads satire within the neo-slave narrative as an evolution in the presentation and discussion of complicated themes, rather than the reinforcement of dominant discourse.

When examining the ways interdisciplinary studies impacts discussions of progress on a global scale one must consider the pedagogical, political, and personal contributions scholars within the discipline make to modern notions of gender and identity. While it is true that significant sites of divergence within the histories and lives of Africandescended people, for example, complicate attempts to claim racial solidarity; throughout the decades important connections have been made in recovery projects that further examine the ways language and rhetoric respond to theory. Sociological and historical examinations of multicultural literature must continue to interrogate linguistic power, with contemporary research providing a space for the confluence of ideas and reimagining. 


\section{REFERENCES}

Andrews, W.L., Foster, F.S. and Harris, T. (Eds.) 1997. The Oxford Companion to African American Literature. Oxford: Oxford University Press.

Bakhtin, M. 1998. “Discourse in the novel”. In Richter, R. (Ed.) The Critical Tradition. Boston: Bedford Books, 530-539.

Barnes, P.C. 1999. "Maryse Condé's I, Tituba, Black Witch of Salem and the Slave Narrative Tradition”. In Liddell, J.L. and Y.B. Kemp (Eds.) Arms Akimbo: Africana Women in Contemporary Literature. Gainesville: University Press of Florida, 193-204.

Breau, E. 1993. “Our Nig”. Callaloo 16 (2), 455-465.

Carby, H.V. 1987. Reconstructing Womanhood: The Emergence of the Afro-American Woman Novelist. Oxford: Oxford University Press.

Carroll, R. 1995. Swing Low: Black Men Writing. New York: Crown Trade Paperbacks.

Condé, M.I. 1992. Tituba Black Witch of Salem. Charlottesville: University Press of Virginia.

hooks, b. 1999 (reprint). Ain't I a Woman: Black Women and Feminism. Cambridge: South End Press.

Dukats, M.L. 1995. “The hybrid terrain of literary imagination: Maryse Condé’s Black Witch of Salem, Nathaniel Hawthorne’s Hester Prynne, and Aimé Césaire’s Heroic Poetic Voice”. College Literature 22, 51-61.

Fanon, F. 1967. Black Skin, White Masks. New York: Grove Press.

Fanon, F. 1994. “On national culture”. In Williams, P. and L. Chrisman (Eds.) Colonial Discourse and Post-Colonial Theory. New York: Columbia University Press, 36-52.

Games, A. 2010. Witchcraft in Early North America. Lanham: Rowman \& Littlefield.

Gandhi, L. 1998. Postcolonial Theory: A Critical Introduction. New York: Columbia University Press. 
Gates, H.L. 2000. "Introduction to The Signifying Monkey: A Theory of Afro-American Literary Criticism”. In Napier, W. (Ed.) African American Literary Theory: A Reader. New York: New York University, 339-347.

Herrmann, C. 1989. The Tongue Snatchers. Lincoln: University of Nebraska Press.

Hutcheon, L. 1988. A Poetics of Postmodernism: History, Theory, Fiction. New York: Routledge.

Jacobs, H. 1987. Incidents in the Life of a Slave Girl. Gates Jr., H.L. (Ed.) New York: Penguin Books.

Jones, G. 1994. "The quest for wholeness: Re-imagining the African American novel, An essay on Third World aesthetics”. Callaloo 12 (2), 507-518.

Jones, H.L. 1969. “Black humor and the American way of life”. Satire 7 (1), 1-10.

Joyce, J.A. 1994. Warriors, Conjurers, and Priests: Defining African-Centered Literary Criticism. Chicago: Third World Press.

Muher, E. 1996. “Isadora at sea: Misogyny as comic capital in Charles Johnson's Middle Passage”. African American Review 30 (4), 649-658.

Mudimbé-Boyi, E. 1993. “Giving a voice to Tituba: The death of the author?” World Literature Today 67, 751-756.

O’Neale, S. 1978. “Ishmael Reed's fitful Flight to Canada: Liberation for some, good reading for all”. Callaloo 4, 174-177.

Rainwater, L. and Yancey, W. 1967. The Moynihan Report and the Politics of Controversy. Massachusetts: Massachusetts Institute of Technology.

Reed, I. 1976. Flight to Canada. New York: Random House.

Rushdy, A. 1999. Neo-slave Narratives: Studies in the Social Logic of a Literary Form. London: Oxford.

Rosenthal, B. 1998. “Tituba’s story”. The New England Quarterly 71, 190-203.

Scarboro, A.A. 1992. “Afterword”. In Condé, M. I, Tituba, Black Witch of Salem (Trans. by Richard Philcox). New York: Ballantine Books, 187-225. 
Williams, P. and Chrisman. L. 1994. Colonial Discourse and Post-Colonial Theory. New York: Columbia University Press.

Received: 30 September 2011

Accepted: 03 December 2012

Cite this article as:

Eaton, K. 2012. "Diasporic dialogues: The role of gender, language, and revision in the newslave narrative”. Language Value 4 (2), 1-22. Jaume I University ePress: Castelló, Spain. http://www.e-revistes.uji.es/languagevalue. DOI: http://dx.doi.org/10.6035/LanguageV.2012.4.2.2

ISSN 1989-7103

Articles are copyrighted by their respective authors 